\title{
The Implementation of Practice Based Simulation of New Nurse Toward Self Confidence: A Literature Review
}

\author{
Yusriani Saleh Baso, Fitri Arofiati \\ Universitas Muhammadiyah Yogyakarta, Indonesia \\ Corresponding author: yusigd4@gmail.com
}

\begin{abstract}
Background: to enhance the quality of nursing service at hospital, it needs learning process (education and training) using clinical skills facility. It gives ideal place for the development of nurse's confident before entering the real world of work. Problem based learning approach is able to use simulation learning method or Practice Based Simulation Model can enhance new nurse's confidence.

Purpose: The objective of this research was to literature review of the practice based simulation that may be expected to enhance new nurse's self confidence.

Methods: This research used Literature Review. Source of the research was taken from some database. Searching was conducted in December 2018 through database of PubMed of 3016 articles, Google Scholar of 13.5000 articles, Science Direct of 3466 articles, Pro Quest of 256 articles using combination of key words "self confidence" and practice based simulation+new graduates nursing. From all database, there were only 7 which fulfilled inclusion criteria.

Results: based on the result of literature review from 7 articles, it was found that applying simulation method to new nurse can enhance self confidence. New nurse would be more independent, able to make decision and conduct nursing care and be more calm while working.
\end{abstract}

Conclusion: the aim of this literature review obtains the result that application of practice based simulation can increase self confidence of nurse.

Key Words: Simulation, self confidence, new nurse, practice 


\section{BACKGROUND}

Nurse is the most human resources in Hospital service. Nurse is an individual who has been graduated from nursing academy/education and able to conduct nursing care or nursing services. Nursing service is a form of professional service which is an integral part of health services based on nursing knowledge and tips aimed at individuals, families, groups, or communities, both healthy and sick, which are supported by human resources who work in accordance with their competencies (Law No. 382014 Concerning Nursing). Therefore, a nurse must have professionalism and confidence in conducting their duties and responsibilities.

Professionalism and self confidence of a nurse can bee seen when they can adapt in working environment and they conduct nursing care well and correctly. A new nurse in making clinical decisions or judgments sometimes still seems hesitant and they cannot decide a decision in solving problems faced in health services, especially in hospitals. It is because they don't believe that to improve the quality of nursing services in the Hospital needs a learning process (education and training) using clinical skills facilities. It provides an ideal place for the development of nurses' learning and self-confidence before entering the real world of work. Self-confidence is a mental attitude possessed by an individual to judge something, thus, the individual can independently conduct something based on the ability they have (Amal, 2016).

Considering about the challenge above, problem based learning is able to use simulation learning method or The Practice Based Simulation Model is a learning model that focuses on students developed to achieve effective and innovative simulation integrity, students in this case are new nurses expected to be able to be involved directly in the learning process based on constructive learning theory which confirms that knowledge is not passively transferred from students, but it is built by students through processing experiences and interactions with their environment (Parker \& Myrick, 2009).

Nursalam (2011) states that simulation is learning method presenting learning using situation or real process. students are actively involved in interacting with the situation in their environment. Simulation is a learning model seeking to bring real situations into lecture classrooms with maximum levels of similarity (Johnston, Coyer, \& Nash, 2017). Simulation is an experience and interaction in making appropriate decisions in conductong nursing care (Liaw et al, 2011).

Experience and interaction with environment can make new nurse to feel confidence in deciding and conducting a nursing action which will be carried out to the patient. Mareno 2014 explains that self-confidence will influence the choice of an individual to make and feel about challenges and disputes. Individuals with a high level of self-confidence will be able to strive to be stronger and successful in conducting their duties. Self-confidence is a mental attitude owned by an individual to assess something. Thus, an individual can independently carry out something based on the ability they have(Afiatin, 1998).

Research conducted by (Crimlisk et al., 2017) states that simulation can add knowledge, cooperate and enhance self-confidence of nurse. In the journal Brown, 2010, it is explained that simulation is an effective teaching strategy in the preparation of health professionals and it is often used to evaluate the clinical judgment and competence of nurses. The same year the research conducted by (Blum, 2010) said that simulations can increase the confidence of a nurse, although not as a whole. Journal (Omer, 2016)explains that using simulation methods as a strategy for clinical education can increase nurse 's confidence. 


\section{OBJECTIVE}

The objective of this research was to literature review of the practice based simulation that may be expected to enhance new nurse's self confidence.

\section{METHODS}

\section{Inclusion Criteria}

The following inclusion criteria were used to study selection for this literature review

1. Research must be related to simulation method presented to nurse

2. This research must give information about the impact of simulation toward self-confidence.

3. The complete text of the study must be available in English and Indonesia

\section{Exclusion Criteria}

It was Unauthorized publications such as letters to editors, absences and editorials.

\section{Data Selection and analysis}

Searching was conducted in December 2018 through database PubMed, Google Scholar, Science Direct database PubMed using key words of "self confidence" of 2.951 articles, using key word "self confidence" and practice based simulation of 38 articles, using key word of "Self confidence" and practice based simulation + nursing new graduates of 27 articles. In searching the Google Scholar Database using the keywords "self confidence" and practice based simulation + new nursing nursing there were 13,500 articles.

In searching the Science Direct Database using the keyword "self confidence", there were 1,287 articles, using the keyword "self-confidence" and practice based simulation obtained 1,831 articles, using the keywords" self-evidence "and practice based simulation + new graduates nursing of 348 article.In searching ProQuest Database using the keywords "self confidence" and practice based simulation + new graduates nursing, there were 256 articles. From the entire database of 20,238 articles, there were only only 7 articles which fulfilled the inclusion criteria.

\section{RESULTS}

The main focus of this literature review was in the application of practice based simulation model of new nurse toward self confidence. To optimize this interpretation, first, review would clarify the result of some researches.

Table 1. Process of Searching the Article

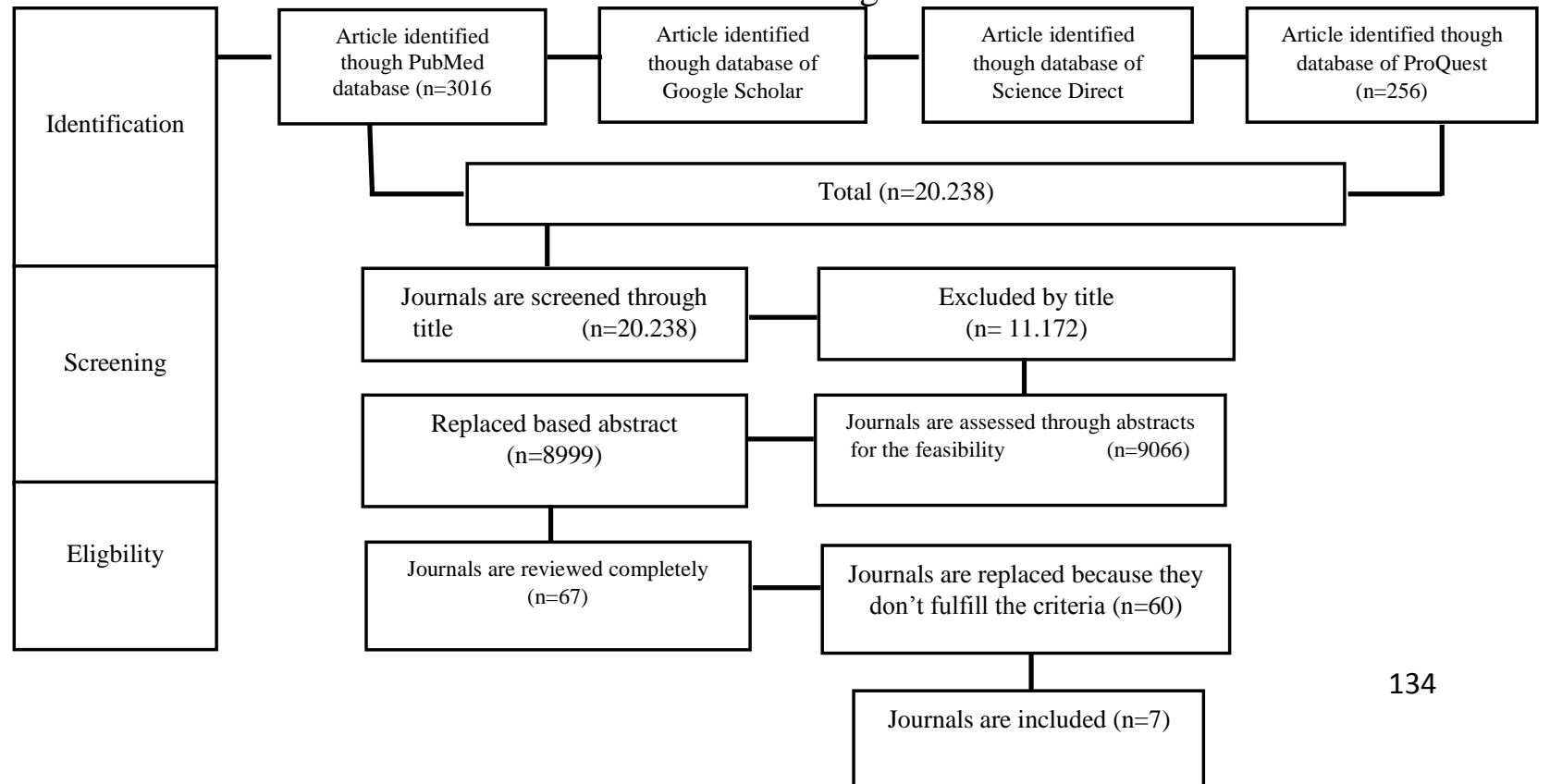


Journal Of Nursing Practice

http://thejnp.org

ISSN: 2614-3488 (print); 2614-3496 (online)

Vol.3 No.2. April 2020. Page.132-142

Include 
Tabel 2. Studi Karakteristik

\begin{tabular}{|c|c|c|c|c|c|c|c|c|c|}
\hline $\begin{array}{l}\mathbf{N} \\
\mathbf{O}\end{array}$ & Source & Objective & Design & Sample & Instrument & $\begin{array}{c}\text { Type of } \\
\text { simulation }\end{array}$ & $\begin{array}{c}\text { Number of } \\
\text { sessions }\end{array}$ & Duration of sessions & Result \\
\hline 1 & $\begin{array}{l}\text { The Effect of } \\
\text { Simulation Learning } \\
\text { on Critical Thinking } \\
\text { and Self-confidence } \\
\text { When Incorporated } \\
\text { Into an } \\
\text { Electrocardiogram } \\
\text { Nursing Course } \\
\text { (Brown \& Chronister, } \\
\text { 2009) }\end{array}$ & $\begin{array}{l}\text { Demonstrate the effect of } \\
\text { simulation activities on } \\
\text { critical thinking and self } \\
\text { confidence in an } \\
\text { electrocardiogram nursing } \\
\text { course }\end{array}$ & $\begin{array}{l}\text { Correlational } \\
\text { research }\end{array}$ & $\begin{array}{l}140 \text { senior-level } \\
\text { baccalaureate } \\
\text { Con }=70 \\
\text { Treatmen }=70\end{array}$ & $\begin{array}{l}\text { Elektrocardio } \\
\text { gram (ECG) } \\
\text { Slim Test }\end{array}$ & $\begin{array}{l}\text { High fidelity } \\
\text { Human } \\
\text { Simulators }\end{array}$ & 5 session & $\begin{array}{l}\text { Treatment }=70 \\
\text { minutes of lecture } \\
\text { and } 30 \text { minutes of } \\
\text { simulation } \\
\text { Activities weekly, } \\
\text { Weeks 2-6 } \\
\text { Control=100 week of } \\
\text { lecture-format } \\
\text { teaching during } \\
\text { weeks 2-5 }\end{array}$ & $\begin{array}{l}\text { The Treatment group did } \\
\text { not show higher levels of } \\
\text { critical thinking,self } \\
\text { confidence than the control } \\
\text { group }\end{array}$ \\
\hline 2 & $\begin{array}{l}\text { New Graduate } \\
\text { Nurses' Perceptions } \\
\text { of the Effects of } \\
\text { Clinical Simulation } \\
\text { on Their Critical } \\
\text { Thinking, Learning, } \\
\text { and Confidence } \\
\text { (Kaddoura, 2010) }\end{array}$ & $\begin{array}{l}\text { Explored the perceptions } \\
\text { of new graduate nurses of } \\
\text { how clinical simula-tion } \\
\text { developed their critical } \\
\text { thinking skills, learning, } \\
\text { and confidence } \\
\text { throughout their hospital } \\
\text { clinical training }\end{array}$ & $\begin{array}{l}\text { Exploratory } \\
\text { descriptive }\end{array}$ & $\begin{array}{l}10 \text { new } \\
\text { baccalaureate } \\
\text { nursing } \\
\text { graduates }\end{array}$ & $\begin{array}{l}\text { Student } \\
\text { Satisfaction } \\
\text { Survey }\end{array}$ & $\begin{array}{l}\text { clinical } \\
\text { simulation }\end{array}$ & $\begin{array}{l}\text { Not } \\
\text { specified }\end{array}$ & 8 hours & $\begin{array}{l}\text { The participants reported } \\
\text { that simulation was } \\
\text { benefi } \neg \text { cial for the } \\
\text { development of critical } \\
\text { thinking skills in their } \\
\text { specialized critical care } \\
\text { units }\end{array}$ \\
\hline 3 & $\begin{array}{l}\text { Implementing } \\
\text { Simulation Training } \\
\text { for New } \\
\text { Cardiothoracic } \\
\text { Intensive Care Unit } \\
\text { Nurses. } \\
\text { (Boling, } \\
\text { Hardin-Pierce, } \\
\text { Jensen, \& Hassan, } \\
\text { 2017) }\end{array}$ & $\begin{array}{l}\text { The objective of this } \\
\text { article was to describe the } \\
\text { process of designing and } \\
\text { implementing a } \\
\text { high-fidelity } \\
\text { simulation training } \\
\text { program as part of a new } \\
\text { graduate } \\
\text { nursing internship }\end{array}$ & Quantitative & $\begin{array}{l}12 \text { new CTICU } \\
\text { Nurses }\end{array}$ & Mannequin & $\begin{array}{l}\text { Scenario of } \\
\text { simulation }\end{array}$ & 2 session & 4 hours & $\begin{array}{l}\text { The focus for the initial } \\
\text { pilot program simulation for } \\
\text { new nurses was in the } \\
\text { development of critical } \\
\text { thinking, enhancement of } \\
\text { learning, and improvement } \\
\text { of confidence. }\end{array}$ \\
\hline
\end{tabular}




\section{Journal Of Nursing Practice}

http://thejnp.org

ISSN: 2614-3488 (print); 2614-3496 (online)

Vol.3 No.2. April 2020. Page.132-142

$4 \quad$ Evaluation of a

High-Fidelity

Simulation

Training Program for

New Cardiothoracic

Intensive Care Unit

Nurses

(Boling,

Hardin-Pierce,

Jensen, \& Hassan, 2016)

This study indicates that

Graduates'

Self-Efficacy Ratings

and

Urinary

Catheterization Skills

in a High Fidelity

Simulation Scenario

Evaluate the effect of a

high-fidelity simulation

raining program on

knowledge and

confidence as part of a

nursing internship in the

cardiothoracic intensive

care unit

$\begin{array}{ll}\text { Quantitative } & \begin{array}{l}10 \quad \text { nurse } \\ \text { interns }\end{array}\end{array}$

Multiple-choi High

ce knowledge Fidelity

test (MCKT), Human

Modified Simulators.

self-efficacy

scale

(MSES),

Simulation

effectiveness

tool (SET)

there is a need for

method with

descriptive

47 New

Graduate Nurs

Mannequin,

Clinical

Competency

Questionnaire

psychomotor skills

correlational

male 5 )

(CCQ)

within the context of a

simulated patient care

situation

Cason, Atz, \&

Horton, 2017)

6 Impact of interactive situated and

simulated teaching

program on novice

nursing practitioners

clinical competence,

Chen, Chen, Lee,

nursing practitioners)

This work aimed to
improve the clinical
competence, promote the
self-confidence, and
reduce the
number of work-related
stressors of NNPs (Novice
nursing practitioners)

control desig

31 NNPs

((Novice

nursing

practitioners)

They were

randomly

allocated into an

ISST group $(\mathrm{n}=$

16) and a

control group (n

=15)

7 Emergency Airway Response Team

Simulation Training:

A

An interprofessional

simulation-based training

study

interventions

63 nurse

emergency

program

was developed to enhance

Nursing Perspective

(Crimlisk et al.,

Response Team (EART)

$\begin{array}{llll}\begin{array}{l}\text { Nursing } \\ \text { Competency } \\ \text { Questionnaire } \\ \text { (NCQ) }\end{array} & \begin{array}{l}\text { Interactive } \\ \text { Situated and }\end{array} & \begin{array}{l}\text { 1 session } \\ \text { every day } \\ \text { Teaching } \\ \text { (ISST) }\end{array} & 6 \text { hours } \\ & & & \\ & & \\ & & \\ & & \\ & & & \\ \text { Protocol } & \text { Video } & 4 \text { session } & \text { 4-hour sessions } \\ \text { Emergency } & \text { simulation } & & \text { were } \\ \text { Air Way } & & & \text { conducted during a } \\ \text { Response for } & & & \text { 12-week period } \\ \text { AHA } & & & \end{array}$

The ISST program for
NNPs significantly
improved their clinical
competence and self
confidence

confidence are 2 of the

major goals of the

orientation training of new

nurses A new nursing graduate that
is competent in
psychomotor skills may
develop higher level critical
clinical judgment,cognitive
abilities and self confidence
Post test 10

minutes
This project supports the use of simulation training to increase nurses" knowledge, confidence, and team dynamics in an EART response 
Journal Of Nursing Practice

http://thejnp.org

ISSN: 2614-3488 (print); 2614-3496 (online)

Vol.3 No.2. April 2020. Page.132-142 


\section{Journal Of Nursing Practice}

http://thejnp.org

ISSN: 2614-3488 (print); 2614-3496 (online)

Vol.3 No.2. April 2020. Page.132-142

\section{DISCUSSION}

\section{Type of Simulation}

Types of Simulation used were large in 7 articles reviewed as follow; 2 (two) High fidelity Human Simulators (Kaddoura, 2010) and (Boling B, 2016), 1 (one) clinical simulation (Sutton, 2014), 1 (one) Scenario of simulation (Bowling B, 2016), 1 (one ) Scenario, Pre test, post test (Horton, 2017), 1 (one) Interactive Situated and Simulated Teaching / ISST (Chen, 2017) and 1 (one) Video simulation (Crimlisk et al., 2017).

\section{Instrument}

Some instrument had been used to enhance self confidence of nurse, in article, it was reviewed as follow: 1 (one) used a mannequin (Bowling B, 2016), 1 (one) used an Electrocardiogram / ECG, Slim Test (Chronister, 2009), 1 (one) used the Student Satisfaction Survey (Kaddoura, 2010), 1 (one) used Multiple -coice knowledge test (MCKT), Modified self-efficacy scale (MSES), Simulation effectiveness tool (SET) (Boling B, 2016), 1 (one) used Mannequin, Clinical Competency Questionnaire / CCQ (Horton, 2017), 1 ( one) used the Nursing Competency Questionnaire / NCQ (Chen, 2017), 1 (one) used the Emergency Air Way Response for AHAs Protocol (Crimlisk et al., 2017).

\section{Effect}

a. It showed higher level of critical thinking and self-confidence (Brown \& Chronister, 2009).

b. Simulations were useful for the development of critical thinking skills in special care units specifically for new nurses (Kaddoura, 2010).

c. Simulation of new nurses was the development of critical thinking, increased learning, and increased self-confidence (Boling B, 2016).

d. It enhanced knowledge and self-confidence are 2 of the main goals of new nurse orientation training (Boling B, 2017).

e. New nursing graduates who were competent in psychomotor skills could develop high-level critical clinical assessments, cognitive abilities and self-confidence (Horton, 2017).

f. Program of ISST for NNP significantly improved clinical competence and self confidence of new nurse (Chen, 2017).

g. The application of simulation training was to increase knowledge, confidence, and dynamics of the nurse team in the EART response (Crimlisk et al., 2017).

\section{Period and Duration}

In article reviewed, research duration and session of simulation training were different.

a. Chronister, 2009, there were 70 minutes care and 30 minutes simulation. Weekly activities were Week 2-6 was Control 100 weeks of teaching lecture format for weeks 2-5.

b. Kaddoura, 2010, the session used was not specific in the article, but the duration used for the simulation was 8 hours.

c. Block B, 2016, the simulation method was conducted in 2 sessions in 4 hours.

d. Horton 2017, the session used was 3 sessions consisting of 10 minutes Pre Test, 30 minutes Treatment, 10 minutes Post Test, but in this article the duration shown in the simulation was not specific.

e. Chen 2017 , the simulation was conducted in 1 session every day for 5 days and the duration used is 4 hours. 


\section{Journal Of Nursing Practice}

http://thejnp.org

ISSN: 2614-3488 (print); 2614-3496 (online)

Vol.3 No.2. April 2020. Page.132-142

f. Crimlisk et al., 2017, simulations conducted in 4 sessions were conducted in a 12-week period.

Self confidence of nurse could be built by having good ability or mental attitude. Thus, it could take good, right and appropriate action or clinical assessment in accordance with the competencies they had (Amal, 2016). Clinical assessment was based on nurses' knowledge and experience and is an important component of effective and safe practice. new nurses currently face the challenges and roles of their new professionals in the increasingly complex environments in which they work in clinical assessment, decision making or decisions to act very important and strong for patient health and safety.

The lack of self confidence of a nurse caused the lack of knowledge about patient specific conditions, technical skills, and clinical knowledge, thus it is endangering patient safety. Self confidence is a mental attitude owned by an individual to assess something so that someone can independently do something based on the ability possessed (See, Morrison, Rothman, \& Soll, 2011).

From 7 articles above, it can be considered that with different tools or instruments, time or duration in conducting different simulations, and the different type of simulation performed different, nurses can think critically and have self confidence in carrying out nursing care. Therefore, nursing care can be carried out properly according to their abilities. With self-confidence, new nurses can also develop clinical assessments of nursing care to be carried out, critical high level, cognitive abilities that can increase self-confidence (Cason et al., 2017)

\section{CONCLUSION}

Practice based simulation model is a learning model focusing on students, developed to achive effective and innovative integrity of simulation. Students in this case are new nurses are expected to be able to be directly involved in the learning process based on constructive learning theory which confirms that non-passive knowledge is transferred from students, but built by students through processing experiences and interactions with their environment. Simulation is conducted by considering the type of simulation used, time or duration and the instrument used during the simulation. With the simulation, it is expected that cognitive abilities, critical thinking and the confidence of a new nurse in clinical assessment to carry out nursing care at the hospital can be carried out properly, correctly and precisely.

The review in this research of literature review is enhancing self confidence of new nurse in conducting clinical judgment or decision making on nursing care conducted at hospital.

Therefore, This literature review could be the basis for further research on simulation methods and the self confidence of new nurses to use a wider range of sources.

\section{LIMITATION OF THE RESEARCH}

In this literature review, researcher only reviewed researches in English with complete texts available in reviewed article 


\section{Journal Of Nursing Practice}

http://thejnp.org

ISSN: 2614-3488 (print); 2614-3496 (online)

Vol.3 No.2. April 2020. Page.132-142

\section{REFERENCES}

Afiatin, T., \& Martaniah, S. M. (1998). Peningkatan kepercayaan diri remaja melalui konseling kelompok. Psikologika: Jurnal Pemikiran dan Penelitian Psikologi, 3(6), 66-79. https://doi.org/10.20885/psikologika.vol3.iss6.art6

Alinier, G., Hunt, B., Gordon, R., \& Harwood, C. (2006). Effectiveness of intermediatefidelity simulation training technology in undergraduate nursing education. Journal of advanced nursing, 54(3), 359-369. https://doi.org/10.1111/j.1365-2648.2006.03810.x

AMAL, A. (2016). SELF-CONFIDENCE OF NURSES TO TREAT SUDDEN DETERIORATION PATIENTS IN MEDICAL WARDS. Nurscope : Jurnal Penelitian dan Pemikiran Ilmiah Keperawatan, 2(2), 51-56. http://dx.doi.org/10.30659/nurscope.2.2.51-56

Blum, C. A. (2010). Using the Benner intuitive-humanistic decision-making model in action: A case study. Nurse Education in practice, 10(5), 303-307. https://doi.org/10.1016/j.nepr.2010.01.009

Boling, B., Hardin-Pierce, M., Jensen, L., \& Hassan, Z. U. (2016, December). Evaluation of a high-fidelity simulation training program for new cardiothoracic intensive care unit nurses. In Seminars in thoracic and cardiovascular surgery (Vol. 28, No. 4, pp. 770-775). WB Saunders. https://doi.org/10.1053/j.semtcvs.2016.11.001

Boling, B., Hardin-Pierce, M., Jensen, L., \& Hassan, Z. U. (2017). Implementing simulation training for new cardiothoracic intensive care unit nurses. Clinical Simulation in Nursing, 13(1), 33-38. https://doi.org/10.1016/j.ecns.2016.09.001

Brown, D., \& Chronister, C. (2009). The effect of simulation learning on critical thinking and self-confidence when incorporated into an electrocardiogram nursing course. Clinical Simulation in Nursing, 5(1), e45-e52.

https://doi.org/10.1016/j.ecns.2008.11.001

Cason, M., Atz, T., \& Horton, L. F. (2017). New nursing graduates' self-efficacy ratings and urinary catheterization skills in a high-fidelity simulation scenario. Clinical Simulation in Nursing, 13(2), 71-77. https://doi.org/10.1016/i.ecns.2016.12.006

Chen, S. H., Chen, S. C., Lee, S. C., Chang, Y. L., \& Yeh, K. Y. (2017). Impact of interactive situated and simulated teaching program on novice nursing practitioners' clinical competence, confidence, and stress. Nurse education today, 55, 11-16. https://doi.org/10.1016/j.nedt.2017.04.025

Crimlisk, J. T., Krisciunas, G. P., Grillone, G. A., Gonzalez, R. M., Winter, M. R., Griever, S. C., ... \& Blumenthal, A. (2017). Emergency airway response team simulation training: a nursing perspective. Dimensions of Critical Care Nursing, 36(5), 290-297. https://doi.org/10.1097/dcc.0000000000000261

Horton-Deutsch, S., \& Sherwood, G. D. (2017). Reflective practice: Transforming education and improving outcomes (Vol. 2). Sigma Theta Tau Book.

Indonesian National Nurses Association. (2014). Law No. 382014 Concerning Nursing. Ministry of Law and Human Rights.

Johnston, S., Coyer, F., \& Nash, R. (2017). Simulation debriefing based on principles of transfer of learning: A pilot study. Nurse education in practice, 26, 102-108.

https://doi.org/10.1016/j.nepr.2017.08.002

Kaddoura, M. A. (2010). New graduate nurses' perceptions of the effects of clinical simulation on their critical thinking, learning, and confidence. The Journal of Continuing Education in Nursing, 41(11), 506-516. https://doi.org/10.3928/00220124-20100701-02 


\section{Journal Of Nursing Practice}

http://thejnp.org

ISSN: 2614-3488 (print); 2614-3496 (online)

Vol.3 No.2. April 2020. Page.132-142

Liaw, S. Y., Scherpbier, A., Klainin- Yobas, P., \& Rethans, J. J. (2011). A review of educational strategies to improve nurses' roles in recognizing and responding to deteriorating patients. International nursing review, 58(3), 296-303.

https://doi.org/10.1111/j.1466-7657.2011.00915.x

McLaughlin, C., Cooper, M., \& Sutton, M. (2014). Simulation: Onboarding Competence with Confidence. Biology of Blood and Marrow Transplantation, 20(2), S304-S305. https://doi.org/10.1016/j.bbmt.2013.12.525

Nursalam. (2011). Manajemen Keperawatan. In Isbn : 978-602-8570-73-2

Omer, T. (2016). Nursing Students' Perceptions of Satisfaction and Self-Confidence with Clinical Simulation Experience. Journal of Education and Practice, 7(5), 131-138.

Parker, B. C., \& Myrick, F. (2009). A critical examination of high-fidelity human patient simulation within the context of nursing pedagogy. Nurse education today, 29(3), 322-329. https://doi.org/10.1016/i.nedt.2008.10.012

See, K. E., Morrison, E. W., Rothman, N. B., \& Soll, J. B. (2011). The detrimental effects of power on confidence, advice taking, and accuracy. Organizational Behavior and Human Decision Processes, 116(2), 272-285.

https://doi.org/10.1016/j.obhdp.2011.07.006 